\title{
Efek Samping Obat terhadap Kepatuhan Pengobatan Antiretroviral Orang dengan HIV/AIDS
}

\author{
Drug Side Effects on Adherence to Antiretroviral Treatment among People \\ Living with HIV/AIDS
}

Fachri Latif, Ida Leida Maria, Muhammad Syafar

Program Pascasarjana Fakultas Kesehatan Masyarakat Universitas Hasanuddin

\begin{abstract}
Abstrak
Tingkat kepatuhan pengobatan antiretroviral di Indonesia sangat rendah, yaitu 40 - 70\%, yang masih di bawah target nasional dengan tingkat kepatuhan 95\%. Berbeda dengan rata-rata nasional, Puskesmas Jumpandang Baru justru memiliki tingkat kepatuhan pengobatan antiretroviral pasien HIVIAIDS di atas 95\%. Penelitian ini bertujuan untuk menganalisis faktor yang paling berpengaruh terhadap kepatuhan pengobatan antiretroviral orang dengan HIVIAIDS (ODHA). Jenis penelitian bersifat observasional analitik dengan pendekatan potong lintang. Populasi penelitian adalah 121 ODHA yang aktif menjalani pengobatan antiretroviral di Puskesmas Jumpandang Baru yang dipilih dengan menggunakan teknik exhaustive sampling. Sampel dalam penelitian ini adalah 121 sampel. Penelitian dilakukan pada 22 April hingga 28 Juni 2014 di klinik Voluntary Counseling and Test Puskesmas Jumpandang Baru Makassar. Analisis data menggunakan uji kai kuadrat dan regresi logistik. Hasil uji kai kuadrat menunjukkan ada hubungan antara pengetahuan, persepsi, riwayat efek samping obat, dukungan keluarga dan teman, serta interaksi antara pasien dengan petugas layanan antiretroviral terhadap kepatuhan pengobatan antiretroviral ODHA. Analisis regresi logistik menunjukan bahwa pengetahuan yang baik, persepsi positif terhadap pengobatan, serta efek samping obat yang tidak dirasakan adalah faktor yang berhubungan dengan kepatuhan pengobatan antiretroviral. Penelitian ini menunjukkan ODHA yang tidak merasakan efek samping obat memiliki kecenderungan terbesar untuk patuh terhadap pengobatan antiretroviral dengan OR sebesar 13,452. Kata kunci: Antiretroviral, efek samping obat, kepatuhan, HIVIAIDS
\end{abstract}

\section{Abstract}

The rate of adherence to antiretroviral treatment in Indonesia is very low, at $40-70 \%$, which is still below our national target (95\%). Different phenomena happens at Jumpandang Baru Primary Health Care, whose level of antiretroviral treatment adherence above $95 \%$. This study aimed to analyze factors that influence the adherence to antiretroviral treatment of people li- ving with HIVIAIDS (PLWH). This study used observational analytic with cross-sectional approach. The population, $121 \mathrm{PLWH}$ are people who actively undergoing antiretroviral treatment in Jumpandang Baru Primary Health Care. By exhaustive sampling technique, the sample size of the study was counted 121 people. The research was conducted on April 22 until June 282014 at Voluntary Counseling and Test Clinic of Jumpandang Baru Primary Health Care, Makassar. Data was analyzed using chi square and logistic regression test. Chi square test showed the relationship between knowledge, perception, drug side effects, family and friends support, and well interaction between PLWH with antiretroviral providers to antiretroviral treatment adherence among PLWH. The logistic regression analysis indicated that high level of knowledge, positive perceived to treatment, and no drug's side effects were the related factors influenced antiretroviral adherence. This result showed that PLWH who do not feel the drug side effects has the greatest propensity to adherence to antiretroviral treatment with an OR of 13.452.

Keywords: Antiretroviral, drug side effects, adherence, HIVIAIDS

\section{Pendahuluan}

Sampai saat ini HIV dan AIDS belum bisa disembuhkan namun infeksi dan replikasi HIV masih bisa dicegah dengan obat. Pengobatan tersebut dikenal dengan terapi pengobatan antiretroviral. ${ }^{1}$ Pengobatan antiretroviral merupakan terapi yang dijalankan orang dengan HIV/AIDS (ODHA) dengan cara mengonsumsi obat seumur hidup. Tujuannya untuk menekan replikasi HIV dalam tubuh. Terapi yang diperlukan untuk menekan replikasi virus secara maksimal adalah 90\% - 95\% dari

Korespondensi: Fachri Latif, Program Pascasarjana FKM Universitas Hasanuddin, Kampus Tamalanrea Jl. Perintis Kemerdekaan KM.10 Makassar (90245), No.Telp: 0411-585658, e-mail: fachrilatif@ymail.com 
semua dosis. ${ }^{2}$

Prevalensi kepatuhan berobat antiretroviral di negara berkembang termasuk Indonesia berada di bawah 95\%, yaitu sekitar 45\% - 70\%. ${ }^{3}$ Penelitian di Kota Makassar pada tahun 2013 menunjukan bahwa ODHA yang menggunakan pengobatan antiretroviral berjumlah 1.029 orang dan yang dinilai kepatuhannya berjumlah 983 . Sebanyak 920 (93,5\%) ODHA memiliki kepatuhan tinggi atau lebih dari 95\% dan $63(6,4 \%)$ ODHA mempunyai kepatuhan rendah atau lebih rendah dari $95 \% .^{4}$ Hasil laporan tersebut menunjukan bahwa kepatuhan pengobatan antiretroviral ODHA di Makassar lebih tinggi dibandingkan dengan hasil pengukuran kepatuhan pengobatan antiretroviral ODHA di Indonesia.

Pengukuran dan pemonitoran kepatuhan pengobatan antiretroviral ODHA, dapat dilakukan di klinik Voluntary Counseling and Test (VCT). ${ }^{5}$ Puskesmas Jumpandang Baru adalah salah satu unit layanan kesehatan di Kota Makassar dengan fasilitas klinik VCT dan layanan pengobatan antiretroviral. Pada tahun 2013, puskesmas tersebut memiliki tingkat kepatuhan pasien ODHA yang tinggi, mencapai 96,9\%.

Beberapa penelitian telah mengungkapkan bahwa terdapat beberapa faktor yang mendorong ODHA untuk patuh terhadap pengobatan antiretroviral. Hasil penelitian mengungkapkan bahwa secara signifikan tingkat pengetahuan berhubungan dengan kepatuhan berobat antiretroviral di Afrika. ${ }^{6}$ Sedangkan persepsi secara signifikan berkaitan dengan kepatuhan minum obat antiretroviral dan faktor persepsi positif merupakan prediktor ketidakpatuhan minum antiretroviral. ${ }^{7}$ Suatu penelitian juga mengungkapkan bahwa interaksi yang baik antara penyedia layanan berpengaruh terhadap kepatuhan pengobatan antiretroviral. ${ }^{8}$ Dukungan sosial yang tinggi dari keluarga, teman sebaya atau sesama ODHA terhadap ODHA memiliki hubungan dengan kepatuhan berobat antiretroviral. ${ }^{9,10}$

Berdasarkan uraian tersebut, penelitian ini bertujuan untuk mengetahui faktor yang paling berpengaruh dengan kepatuhan pengobatan antiretroviral ODHA di Puskesmas Jumpandang Baru Kota Makassar.

\section{Metode}

Jenis penelitian bersifat observasional analitik melalui rancangan potong lintang. Populasi dalam penelitian adalah 121 pasien penderita HIV yang aktif menjalani pengobatan antiretroviral di klinik VCT Puskesmas Jumpandang Baru Kota Makassar terhitung akhir bulan Mei 2014. Berdasarkan hasil perhitungan besar sampel dengan menggunakan aplikasi Simple Size 2.0 WHO didapatkan jumlah sampel minimal adalah 94 orang. Teknik penarikan sampel dalam penelitian ini dilakukan dengan cara exhaustive sampling yang berarti semua anggota populasi dapat diambil sebagai sampel dalam penelitian sehingga sampel yang digunakan berjumlah 121 orang. Kriteria inklusi sampel adalah ODHA berusia di atas 15 tahun serta berdomisili di Kota Makassar, Gowa, dan Maros. Sedangkan kriteria eksklusi adalah ODHA dengan masa pengobatan kurang dari satu bulan.

Untuk memperhatikan jaminan keamanan dan kerahasiaan data responden ODHA dalam hasil penelitian, penelitian ini dilengkapi ethical clearance yang dikeluarkan oleh Komisi Etik Fakultas Kedokteran Universitas Hasanuddin dengan nomor registrasi UH1404019.

Pengumpulan data menggunakan kuesioner. Pengukuran kepatuhan minum obat pasien dilakukan dengan teknik self report, yaitu meminta pasien mengingat jumlah obat yang mereka sisa, menghitung sisa jumlah obat yang tidak diminum, dan memvalidasi keterangan minum obat ODHA pada pengawas minum obat yang berasal dari keluarga atau pendamping mereka. Wawancara dilakukan dengan dua cara, yaitu mengunjungi tempat yang disepakati oleh calon responden saat perjanjian sebelumnya dan pengumpulan data di puskesmas yang dilakukan dengan cara menunggu kedatangan jadwal pengambilan obat para ODHA di klinik VCT Puskesmas Jumpandang Baru Kota Makassar.

Data yang telah dikumpulkan dianalisis dengan sistem komputerisasi program SPSS melalui editing, coding, entry, cleaning, serta analisis data. Data yang terkumpul melalui observasi dan wawancara kemudian dianalisis dengan metode analisis univariat, analisis bivariat dengan menggunakan uji kai kadrat, dan analisis multivariat dengan menggunakan uji regresi logistik.

\section{Hasil}

Dari 121 sampel, hanya 103 pasien yang berhasil didata dan dilakukan analisis data karena terdapat ODHA di klinik VCT Puskesmas Jumpandang baru yang tidak kooperatif dan tidak bersedia menjadi responden dalam penelitian ini. Hasil analisis univariat menunjukkan bahwa lebih banyak responden laki-laki $(74,8 \%)$ dibandingkan perempuan. Jumlah responden dengan usia dewasa (26 - 35 tahun) paling besar proporsinya yaitu $70,9 \%$. Sedangkan tingkat pendidikan terakhir responden terbesar adalah SMA yaitu $62,1 \%$ dan status pekerjaan responden terbanyak adalah berdagang $(40,8 \%)$ (Tabel 1).

Distribusi responden berdasarkan lama menjalani pengobatan antiretroviral ODHA menunjukan bahwa paling banyak responden telah melakukan terapi antiretroviral lebih dari dua tahun $(63,1 \%)$. Hasil penelitian juga diperoleh bahwa jenis obat yang dikonsumsi ODHA adalah jenis obat antiretroviral lini pertama dengan jenis kombinasi obat yang paling banyak dikonsumsi adalah kombinasi jenis obat Duviral + Evafir dengan proporsi sebesar $45,6 \%$.

Hasil analisis bivariat menunjukkan bahwa jumlah 
Tabel 1. Distribusi Responden Berdasarkan Karakteristik Pasien ODHA

\begin{tabular}{|c|c|c|c|}
\hline \multirow{2}{*}{ Karakteristik Responden } & \multirow{2}{*}{ Kategori } & \multicolumn{2}{|c|}{ Jumlah Responden } \\
\hline & & $n=103$ & $\%$ \\
\hline \multirow[t]{2}{*}{ Jenis kelamin } & Laki-laki & 77 & 74,8 \\
\hline & Perempuan & 26 & 25,2 \\
\hline \multirow[t]{4}{*}{ Golongan usia } & $17-25$ tahun & 5 & 4,9 \\
\hline & 26- 35 tahun & 73 & 70,9 \\
\hline & 36- 45 tahun & 21 & 20,4 \\
\hline & $>45$ tahun & 4 & 3,9 \\
\hline \multirow[t]{7}{*}{ Pendidikan terakhir } & Tidak tamat SD & 2 & 1,9 \\
\hline & SD & 5 & 4,9 \\
\hline & SMP & 9 & 8,7 \\
\hline & SMA & 64 & 62,1 \\
\hline & D3 & 8 & 7,8 \\
\hline & S1 & 14 & 13,6 \\
\hline & S2 & 1 & 1,0 \\
\hline \multirow{4}{*}{ Status perkawinan } & Menikah & 64 & 62,1 \\
\hline & Belum menikah & 30 & 29,1 \\
\hline & Janda & 3 & 2,9 \\
\hline & Duda & 6 & 5,8 \\
\hline \multirow[t]{6}{*}{ Pekerjaan } & PNS & 5 & 4,9 \\
\hline & Pegawai swasta & 21 & 20,4 \\
\hline & Wiraswasta/pedagang & 42 & 40,8 \\
\hline & Buruh & 8 & 7,8 \\
\hline & Ibu rumah tangga & 17 & 16,5 \\
\hline & Tidak bekerja & 10 & 9,7 \\
\hline \multirow[t]{11}{*}{ Lama terapi antiretroviral } & $<1$ tahun & 5 & 4,9 \\
\hline & 1 tahun & 16 & 15,5 \\
\hline & 2 tahun & 17 & 16,5 \\
\hline & 3 tahun & 15 & 14,6 \\
\hline & 4 tahun & 16 & 15,5 \\
\hline & 5 tahun & 9 & 8,7 \\
\hline & 6 tahun & 7 & 6,8 \\
\hline & 7 tahun & 7 & 6,8 \\
\hline & 8 tahun & 4 & 3,9 \\
\hline & 9 tahun & 3 & 2,9 \\
\hline & $>9$ tahun & 4 & 3,9 \\
\hline \multirow{4}{*}{$\begin{array}{l}\text { Jenis kombinasi obat antiretroviral } \\
\text { yang dikonsumsi ODHA }\end{array}$} & Duviral + Neviral & 30 & 29,1 \\
\hline & Duviral + Evafirens & 47 & 45,6 \\
\hline & Tenovofir (TDF) + Hiviral + Neviral & 12 & 11,7 \\
\hline & Tenovofir (TDF) + Hiviral + Evafirens & 14 & 13,6 \\
\hline
\end{tabular}

responden yang tergolong patuh terhadap pengobatan antiretroviral sebanyak 92 orang $(86,7 \%)$, lebih banyak dibandingkan responden yang tergolong tidak patuh dalam pengobatan antiretroviral yang berjumlah 11 orang $(13,3 \%)$. Proporsi ODHA yang berpendidikan tinggi dan patuh lebih besar yaitu 90,8\% dibandingkan dengan ODHA berpendidikan rendah dan patuh sebesar $81,2 \%$. Sedangkan proporsi responden perempuan yang patuh lebih besar $(100 \%)$ daripada responden laki-laki $(85,7 \%)$.

Pada uji kai kuadrat menunjukan bahwa tidak terdapat hubungan antara faktor usia (nilai $p=1,000$ ), jenis kelamin (nilai $\mathrm{p}=0,061$ ), dan tingkat pendidikan (nilai $\mathrm{p}=0,379$ ) dengan kepatuhan pengobatan antiretroviral. Hasil ini didukung dengan adanya perbedaan proporsi responden yang patuh dan berpengetahuan cukup baik memiliki persentasi yang lebih besar dibandingkan dengan responden berpengetahuan rendah tidak patuh. Pada analisis uji kai kuadrat menunjukan bahwa faktor pengetahuan (nilai $p=0,002$ ), persepsi (nilai $p=0,015$ ), dan riwayat efek samping obat (nilai $\mathrm{p}=0,016$ ) berhubungan signifikan terhadap kepatuhan pengobatan antiretroviral. Akses ke layanan pengobatan ditemukan tidak ada hubungan yang signifikan dengan kepatuhan pengobatan antiretroviral (nilai $\mathrm{p}=0,111$ ) (Tabel 2).

Hasil penelitian terhadap variabel dukungan keluarga dan dukungan teman mengungkapkan bahwa proporsi responden tergolong patuh minum obat yang mendapatkan dukungan tinggi dari keluarga lebih besar dibandingkan responden dengan yang tidak patuh. Pada Tabel 2, dukungan keluarga (nilai $p=0,018$ ) dan dukungan teman (nilai $\mathrm{p}=0,042$ ) memiliki hubungan bermakna terhadap kepatuhan pengobatan antiretroviral para ODHA.

Hasil analisis uji regresi logistik bertingkat pada tahap akhir menunjukan bahwa terdapat hubungan yang bermakna antara pengetahuan yang cukup tentang pengobatan antiretroviral, persepsi positif terhadap pengo- 
Tabel 2. Hasil Analisis Bivariat Kepatuhan Pengobatan Antiretroviral

\begin{tabular}{|c|c|c|c|c|c|c|}
\hline \multirow{3}{*}{ Variabel } & \multirow{3}{*}{ Kategori } & \multicolumn{4}{|c|}{ Kategori Kepatuhan $(n=103)$} & \multirow{3}{*}{ Nilai $p$} \\
\hline & & \multicolumn{2}{|c|}{ Patuh } & \multicolumn{2}{|c|}{ Tidak Patuh } & \\
\hline & & $\mathrm{n}=92$ & $\%$ & $n=11$ & $\%$ & \\
\hline \multirow[t]{2}{*}{ Pengetahuan tentang pengobatan antiretroviral } & Cukup & 71 & 95,9 & 3 & 4,1 & 0,002 \\
\hline & Kurang & 21 & 72,4 & 8 & 27,6 & \\
\hline \multirow{2}{*}{ Persepsi terhadap pengobatan } & Positif & 64 & 95,5 & 3 & 4,5 & 0,015 \\
\hline & Negatif & 28 & 77,8 & 8 & 22,2 & \\
\hline \multirow[t]{2}{*}{ Riwayat efek samping obat } & Tidak merasakan & 63 & 95,5 & 3 & 4,5 & 0,016 \\
\hline & Merasakan & 29 & 78,4 & 8 & 21,6 & \\
\hline \multirow{2}{*}{ Akses ke layanan antiretroviral } & Mudah & 50 & 84,7 & 9 & 15,3 & 0,111 \\
\hline & Sulit & 42 & 95,5 & 2 & 4,5 & \\
\hline \multirow[t]{2}{*}{ Dukungan keluarga } & Tinggi/baik & 74 & 93,7 & 5 & 6,3 & 0,018 \\
\hline & Kurang & 18 & 75,0 & 6 & 25,0 & \\
\hline \multirow[t]{2}{*}{ Dukungan teman } & Tinggi/baik & 64 & 94,1 & 4 & 5,9 & 0,042 \\
\hline & Kurang & 28 & 80,0 & 7 & 20,0 & \\
\hline \multirow[t]{2}{*}{ Interaksi pasien dengan petugas layanan antiretroviral } & Baik & 71 & 94,7 & 4 & 5,3 & 0,008 \\
\hline & Buruk & 21 & 75,0 & 7 & 25,0 & \\
\hline
\end{tabular}

Tabel 3. Hasil Analisis Regresi Logistik Faktor yang Berhubungan dengan Kepatuhan Pengobatan Antiretroviral Pasien ODHA

\begin{tabular}{|c|c|c|c|c|c|c|}
\hline \multirow{2}{*}{ Variabel Independen } & \multirow{2}{*}{ B } & \multirow{2}{*}{ SE } & \multirow{2}{*}{ Nilai p } & \multirow{2}{*}{ OR } & \multicolumn{2}{|c|}{ 95\% CI } \\
\hline & & & & & Lower & Upper \\
\hline Pengetahuan (tinggi) & 2,551 & 0,989 & 0,010 & 12,821 & 1,845 & 89,105 \\
\hline Persepsi (positif) & 2,363 & 0,019 & 0,020 & 10,627 & 1,442 & 78,344 \\
\hline Riwayat efek samping obat (tidak pernah merasakan efek samping) & 2,599 & 0,038 & 0,012 & 13,452 & 1,760 & 102,813 \\
\hline Akses ke layanan antiretroviral (mudah) & $-1,762$ & 1,075 & 0,101 & 0,172 & 0,021 & 1,411 \\
\hline Constant & $-5,398$ & 0,570 & 0,001 & 0,005 & & \\
\hline
\end{tabular}

batan antiretroviral, dan tidak merasakan efek samping obat dengan kepatuhan pengobatan antiretroviral ODHA di Puskesmas Jumpandang Baru Kota Makassar (Tabel 3).

Faktor yang dominan berhubungan kuat terhadap kepatuhan pengobatan antiretroviral para ODHA di Puskesmas Jumpandang Baru Kota Makassar adalah riwayat tidak merasakan efek samping obat antiretroviral dengan nilai OR $=13,452$ (Tabel 3).

\section{Pembahasan}

Kepatuhan adalah faktor yang paling penting dalam mencapai keberhasilan virologi dari terapi pengobatan antiretroviral. ${ }^{11}$ Untuk dapat menekan replikasi virus secara maksimal, setidaknya pasien ODHA harus mencapai kepatuhan 90\% - 95\% yang berarti 90\% - 95\% dari semua dosis wajib diminum tepat waktu. ${ }^{12}$ Salah satu faktor yang berpengaruh terhadap kepatuhan dan ketidakpatuhan seseorang dalam mengonsumsi obat antiretroviral adalah karena merasakan reaksi efek samping obat yang menganggu dan berlangsung cukup lama. ${ }^{13}$

Hasil analisis bivariat menunjukan bahwa terdapat hubungan yang bermakna antara efek samping pengobatan dengan kepatuhan pengobatan antiretroviral pasien penderita HIV di klinik VCT Puskesmas Jumpandang Baru Kota Makassar. Hasil ini sejalan de- ngan penelitian Ramadian dan Ritiawan, ${ }^{14}$ yang menyelidiki tentang pengaruh efek samping obat dengan kepatuhan minum obat ODHA terapi antiretroviral lini pertama di Rumah Sakit Cipto Mangunkusumo Jakarta dan berhasil mengungkapkan bahwa terdapat hubungan yang signifikan antara efek samping obat dengan kepatuhan pengobatan antiretroviral pasien HIV.

Hasil uji regresi logistik menunjukan bahwa riwayat tidak merasakan efek samping obat secara signifikan berhubungan dengan kepatuhan pengobatan antiretroviral. ODHA yang tidak pernah merasakan efek samping obat antiretroviral dalam sebulan memiliki kemungkinan 13 - 14 kali untuk patuh terhadap pengobatan dibandingkan dengan yang merasakan efek samping obat. Hasil tersebut konsisten dengan penelitian Ayalu dan Biadgilign, 15 yang mengungkapkan bahwa pasien yang tidak mengalami efek samping obat akan 13 kali lebih patuh terhadap pengobatan dibandingkan dengan yang sering merasakan efek samping obat antiretroviral.

Reaksi hipersensitivitas atau efek samping yang berlebihan karena obat lebih sering terjadi pada pasien HIV dibandingkan dengan populasi umum. Alasan mengapa penderita HIV mengalami reaksi hipersensitivitas lebih sering bersifat multifaktorial, seperti faktor hiperaktivasi imunitas, perubahan dalam metabolisme obat, profil sitokin, stres oksidatif, dan predisposisi genetika. ${ }^{16}$ 
Efek samping obat antiretroviral umumnya terjadi dalam tiga bulan pertama, namun tidak semua ODHA akan mengalami efek samping setelah minum obat antiretroviral. ${ }^{17}$ Pernyataan ini didukung dengan penelitian seorang ahli di Nigeria yang mengungkapkan bahwa efek samping obat lebih mungkin terjadi pada pasien yang menjalani antiretroviral pada enam bulan pertama pengobatan yaitu 6 -12 bulan dan 12 - 24 bulan dibandingkan dengan yang telah lama melakukan terapi antiretroviral. ${ }^{18} \mathrm{Hal}$ ini tidak sesuai dengan pernyataan yang diberikan oleh Kammerer et al, ${ }^{19}$, bahwa semakin lama terapi dan sakit yang diderita, risiko terjadinya penurunan tingkat kepatuhan semakin tinggi.

Perbedaan tersebut disebabkan adanya persepsi positif tentang manfaat obat antiretroviral yang dirasakan para ODHA yang melakukan terapi antiretroviral di Puskesmas Jumpandang Baru ketika mengonsumsi obat. Hasil penelitian diperoleh $62,1 \%$ atau 64 responden menyatakan efek samping obat antiretroviral yang selalu muncul tidak membuat malas meminum obat. Hasil tersebut didukung dengan hasil penelitian sebelumnya yang dilakukan O'Connor et al, ${ }^{20}$ yang menyatakan bahwa persepsi ODHA terhadap obat antiretroviral dapat meningkatkan status kesehatan akan membuat ODHA 3 - 4 kali lebih patuh terhadap pengobatan dibandingkan yang memiliki persepsi negatif.

Penelitian ini memiliki beberapa keterbatasan yaitu untuk menilai kepatuhan ODHA melalui kuesioner kepatuhan self report serta validasi dari keluarga atau teman ODHA yang dianggap sebagai pengawas minum obat mereka yang mungkin melebih-lebihkan kepatuhan keluarga mereka serta perhitungan jumlah tablet responden dilakukan dengan mengandalkan ingatan para ODHA untuk mengingat kembali jumlah obat yang mereka minum dan mereka sisa selama sebulan terakhir menjalani pengobatan. Untuk mengatasi hal tersebut, peneliti mencocokan data hasil pengakuan wawancara responden dengan data laporan pengobatan sebulan terakhir pasien ODHA yang dicatat oleh petugas VCT di puskesmas.

\section{Kesimpulan}

Berdasarkan hasil penelitian tentang kepatuhan pengobatan antiretroviral pada 103 responden yang berobat di Puskemas Jumpandang Baru Kota Makassar, dapat disimpulkan bahwa terdapat hubungan antara pengetahuan, persepsi terhadap obat, dan riwayat efek samping obat terhadap kepatuhan pengobatan antiretroviral. Riwayat tidak pernah merasakan efek samping obat memiliki pengaruh kuat terhadap kepatuhan pengobatan antiretroviral ODHA.

\section{Saran}

Hasil penelitian diharapkan dapat dijadikan bahan masukan untuk pihak Puskesmas Jumpandang Baru dan pihak puskesmas yang memiliki layanan pengobatan antiretroviral di Kota Makassar. Pemberian edukasi dan motivasi mengenai efek samping obat perlu dilakukan oleh petugas layanan antiretroviral kepada ODHA dan keluarga ODHA sehingga keluarga ODHA juga memahami bahwa efek samping bukanlah suatu penghalang untuk patuh mengonsumsi obat antiretroviral sehingga tidak memberikan dampak negatif terhadap kesehatan para ODHA.

\section{Daftar Pustaka}

1. World Health Organization. Antiretroviral therapy for HIV Infection in adults and adolescents [online]. Geneva: World Health Organization; 2010 [cited 2013 Aug 5]. Available from: http://apps.who.int/iris/bitstream/10665/44379/1/9789241599764_eng.pdf.

2. Nasronuddin. HIV dan AIDS: pendekatan biologi molekuler, klinis, dan sosial. Edisi ke-2. Surabaya: Airlangga University Press; 2012.

3. Pusat Penelitian HIV/AIDS Universitas Atmajaya. Interaksi metadon dan ARV dalam pengaruhnya terhadap adherence [online]. Jakarta: AIDS Reaserch Center Atmajaya; 2013 [diakses tangganl 17 Januari 2014]. Diunduh dalam: http://www.arc-atmajaya.org/dikti.

4. Dinas Kesehatan Kota Makassar. Laporan jumlah penderita HIV/AIDS dan perawatan ARV pasien HIV. Makassar, Sulawesi Selatan: Dinas Kesehatan kota Makassar; 2013.

5. Direktorat Jenderal Pengendalian Penyakit dan Penyehatan Lingkungan Kementerian Kesehatan Republik Indonesia. Pedoman nasional tatalakasan klinis infeksi HIV dan terapi antiretroviral pada orang dewasa. Jakarta: Kementerian Kesehatan Republik Indonesia; 2011.

6. Ramadhanianto F. Pelayanan VCT (voluntary counseling and testing) [online]. Surabaya: 2013 [diakses tanggal 17 Januari 2014]. Available from:http://r-fahmi-p-fkm11.web.unair.ac.id/artikel_detail_697 50_Kesehatan_Pelayanan_VCT_Voluntary_Counseling_and_ Testing.html.

7. Oyore JP, Mwanzo IJ, Orago ASS, Odhiambo-Otieno GW. Determinants of adherence to antiretroviral therapy (ART) among patients attending public and private health facilities in Nairobi. Kenya Journal of AIDS and HIV Research (JAIDS). 2013; 5(3): 70-4.

8. Oku AO, Owoaje ET, Ige OK, Oyo-Ita A. Prevalence and determinants of adherence to HAART amongst PLHIV in a tertiary health facility in South-South Nigeria. BMC Infectious Disease. 2013; 13: 401.

9. Kiran B, Karki DK, Lohani SP, Thapa R, Aryal UR, Pathak LR. Adherence to anti-retroviral therapy among people living with HIV and AIDS in Far West, Nepal. Asian Journal of Medical Sciences. 2011; 2 (1): 7-13.

10. Wasti SP, Simkhada P, Randall J, Freeman JV, van Teijlingen E. Factors influencing adherence to antiretroviral treatment in Nepal: a mixedmethods study. PloS one. 2012; 7 (5): e35547.

11. Ubra RR. Faktor-faktor yang berhubungan dengan kepatuhan pengobatan minum ARV pada pasien HIV di Kabupaten Mimika-Provinsi Papua Tahun 2012 [tesis]. Depok: Fakultas Kesehatan Masyarakat Universitas Indonesia; 2012.

12. Cambiano V, Lampev FC, Rodger AJ, Smith CJ, Gereth AM, Lodwick RK. Long-Term trends in adherence to antiretroviral therapy from start 
of HAART. AIDS. 2010 May 15; 24 (8): 1153-62.

13. Amberbir A, Woldemichael K, Getachew S, Girma B, Deribe K. Predictors of adherence to antiretroviral therapy among HIV-infected persons: a prospective study in Southwest Ethiopia. BMC Public Health. 2008; 8 (1): 265.

14. Okki R. Pengaruh efek samping antiretroviral lini pertama HIV dan AIDS Rumah Sakit Cipto Mangunkusumo (RSCM) [laporan penelitian]. Indonesia: AIDS-INA; 2010.

15. Ayalu AR, Biadgilign S. Determinants of adherence to antiretroviral therapy among HIV-infected patients in Africa. AIDS research and treatment. 2012; 2012: 574656.

16. Nursalam MN. Asuhan keperawatan pada pasien terinfeksi HIV/AIDS. Jakarta: Salemba Medika; 2007.

17. Ditjen Pengendalian Penyakit dan Penyehatan Lingkungan Departemen
Kesehatan Republik Indonesia. Pedoman nasional terapi antiretroviral. Paduan tatalakasan klinis infeksi HIV pada orang dewasa dan remaja. Edisi ke-2. Jakarta: Kementrian Kesehatan Republik Indonesia.

18. Eluwa GI, Badru T, Agu KA, Akpoigbe KJ, Chabikuli O, Hamelmann C. Adverse drug reactions to antiretroviral therapy (ARVs): Incidence, type and risk factors in Nigeria. BMC Clinical Pharmacology. 2012;12: 7.

19. Kammerer J, Garry G, Hartigan M, Carter B, Erlich L. Adherence in patients on dialysis: Strategies for success. Nephrology Nursing Journal [Iserial on internet]. 2007 Oct [cited 2014 Aug 18]; 34(5):[479 p.]. Available from: http://esrdnetwork6.org.

20. O'Connor JL, Gardner EM, Mannheimer SB, Lifson AR, Esser S, Telzak EE, et al. Factors associated with adherence amongst 5295 people receiving antiretroviral therapy as part of an international trial. Journal of Infectious Diseases. 2013; 208 (1): 40-9. 